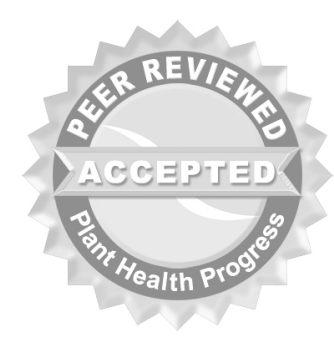

(C) 2008 Plant Management Network.

Accepted for publication 20 December 2007. Published 14 March 2008.

\title{
Filtration to Eliminate Phytophthora spp. from Recirculating Water Systems in Commercial Nurseries
}

\author{
Thorsten Ufer and Sabine Werres, Federal Biological Research \\ Center for Agriculture and Forestry, Institute for Plant Protection in \\ Horticulture, 38104 Braunschweig, Germany; Martin Posner, \\ Baumschulberatungsring Weser-Ems e.V., 26655 Westerstede, \\ Germany; and Hans-Peter Wessels, Chamber of Agriculture \\ Nordrhein-Westfalen, 48167 Münster-Wolbeck, Germany
}

Corresponding author: Sabine Werres. Sabine.Werres@jki.bund.de

Ufer, T., Werres, S. K., Posner, M., and Wessels, H.-P. 2008. Filtration to eliminate Phytophthora spp. from recirculating water systems in commercial nurseries. Online. Plant Health Progress doi:10.1094/PHP-2008-0314-01-RS.

\begin{abstract}
Three filtration systems using slow sand filtration (SSF) and one using lava grain filtration (LGF) were tested for their ability to eliminate Phytophthora spp. from recycled water in commercial ornamental nurseries over four years. Samples were taken in May, August, and October of each year. Phytophthora spp. could not be detected in any of the filter effluents when filters were operating normally. Water stored in clean water reservoirs that were filled only with filtered water and were well protected from contamination via soil and air remained free of Phytophthora. All four filtration systems produced sufficient quantities of water for nursery production. The maximum annual quantity of water demanded by the nurseries ranged from 30,000 to $163,000 \mathrm{~m}^{3}$. The cost for $1 \mathrm{~m}^{3}$ filtered water was lowest for slow sand filtration compared with lava grain filtration. Recommendations for designing systems suitable for large ornamental nurseries with open air recycling systems are discussed.
\end{abstract}

\section{I ntroduction}

Phytophthora species are one of the most important groups of plant pathogens able to be spread with contaminated water $(1,20,21)$. Many Phytophthora species, e.g., P. cactorum, P. cinnamomi, and the quarantine organism, P. ramorum, have a wide host range while others like P. alni (alder decline) and the quarantine organism $P$. fragariae var. fragariae (red core of strawberries) are specialized on single-host plants. Phytophthora species need water for the development of sporangia and motile zoospores, which are of great importance for plant infection.

Epidemiological studies in commercial nurseries showed that Phytophthora species can be present in the water recirculation systems during all seasons $(5,13,17,19)$. Thus, effective methods to decontaminate irrigation water in commercial nurseries are essential. Chemical treatment of the water in open air recycling systems is not allowed in all countries. Furthermore, chemical treatment might kill beneficial organisms. Other methods, like UV radiation, may not be successful with water containing suspended particulates as is normally found in open air water recycling systems. In German nurseries, large water reservoirs very often provide habitat for water plants and animals like birds and fishes. Therefore, environmentally acceptable methods like filtration systems should be considered for use. Filtration systems have been tested successfully for water decontamination in horticultural glasshouse production $(15,22)$. Information for container grown, woody ornamentals in outdoor production exists only from trials in small, pilot scale filtration systems (18). There is no scientific information on their efficiency with large water volumes open air water recirculation systems in commercial nurseries. Therefore, the aim of this study was to test the ability of two different filtration systems - slow 
sand filtration (SSF) and lava grain filtration (LGF) - to eliminate

Phytophthora spp. from recycled water under commercial conditions.

\section{Nurseries and Water Recirculation Systems}

The four nurseries involved in the studies had container areas between 5 and 15 ha (Table 1). The range of plants produced at each nursery varied from having great diversity to a high degree of specialization. Rhododendron and ornamental conifers were the most important plants. All four nurseries produced container plants on open air growing areas. The surplus water was collected from container blocks by drainage systems that lead the water to retention basins (Fig. 1). In all nurseries, these retention basins were open air ponds of different storage capacities. Water was taken from these ponds for irrigation and also for frost protection by irrigation. If water became limited, the retention basins were supplemented with water from wells. In all four nurseries, the water from the retention basins was pumped directly onto the surface of the filters (Fig. 1).

Table 1. Characterization of the production areas and the water recirculation systems of four commercial ornamental nurseries using either slow sand filtration or lava grain filtration used in this study.

\begin{tabular}{|l|l|l|l|l|l|}
\hline Nursery & SSF 1 & SSF 2 & SSF 3 & LGF \\
\hline Production area (ha) & 11 & 5 & 5 & 15 \\
\hline I rrigation system & sprinkler & sprinkler & $\begin{array}{l}\text { - booms } \\
\text { - sprinkler }\end{array}$ & $\begin{array}{l}\text { - booms - drip irrigation } \\
\text { - sprinkler }\end{array}$ \\
\hline Drainage system & $\begin{array}{l}\text { horizontal } \\
\text { slope }\end{array}$ & $\begin{array}{l}\text { horizontal } \\
\text { slope }\end{array}$ & $\begin{array}{l}\text { horizontal } \\
\text { slope }\end{array}$ & vertical \\
\hline $\begin{array}{l}\text { Retention } \\
\text { reservoir }\end{array}$ & Construction & in-ground & in-ground & in-ground & above-ground \\
\cline { 2 - 6 } & $\begin{array}{l}\text { earthen } \\
\text { basin } \\
\text { ground of } \\
\text { dense clay }\end{array}$ & $\begin{array}{l}\text { earthen } \\
\text { basin } \\
\text { ground of } \\
\text { dense clay }\end{array}$ & $\begin{array}{l}\text { earthen } \\
\text { basin } \\
\text { ground of } \\
\text { dense clay }\end{array}$ & $\begin{array}{l}\text { earthen basin } \\
\text { wround covered } \\
\text { geomembrane } \\
\text { liner }\end{array}$ \\
\cline { 2 - 6 } & Size $\left(\mathrm{m}^{3}\right)$ & 3,000 & 30,000 & $\begin{array}{l}1,500 \\
\text { (since } \\
2005: \\
2,000)\end{array}$ & 25,000 \\
\hline
\end{tabular}

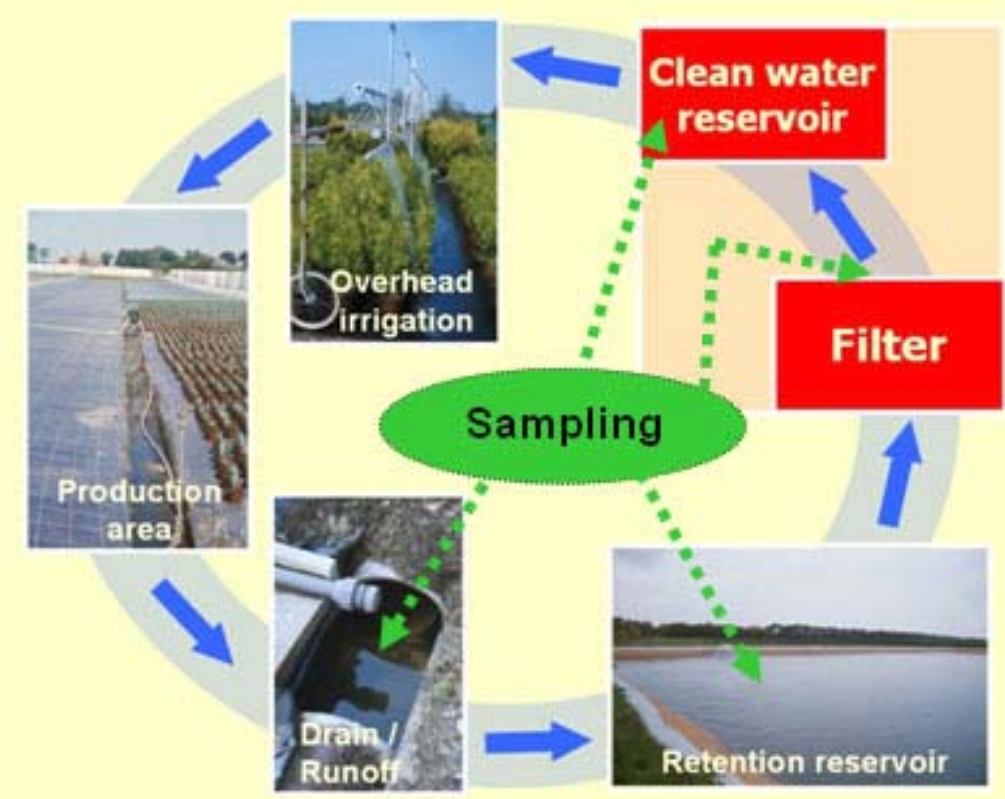

Fig. 1. Diagram of a water recycling system in container nurseries. 


\section{Filtration Systems}

Two filtration methods were tested: SSF (9) and LGF (11). SSF was tested in three nurseries designated SSF 1, SSF 2, and SSF 3. The SSF systems consisted of graded gravel at the bottom (under-drain) and a fine-grained sand layer as filter medium at the top (Fig. 2). The water flowed slowly $(\leq 0.3 \mathrm{~m} / \mathrm{h})$ through the layers and was collected as soon as it passed through the bottom layer. A layer of beneficial microorganisms developed at the sand/water interface at the top of the filter system. SSF 1 and SSF 3 the filtration systems were constructed in the ground and were not covered. These two systems had filter surfaces of 324 and $100 \mathrm{~m}^{2}$ and a filtration capacity of 90 and $30 \mathrm{~m}^{3} / \mathrm{h}$, respectively (Table 2). SSF 3 combined a part of a former retention reservoir that was modified in 2006 to have a new clean water reservoir. The SSF 2 filtration system was constructed using a covered steel tank. It had a filter surface of $260 \mathrm{~m}^{2}$ and a filter capacity of $70 \mathrm{~m}^{3} / \mathrm{h}$. 


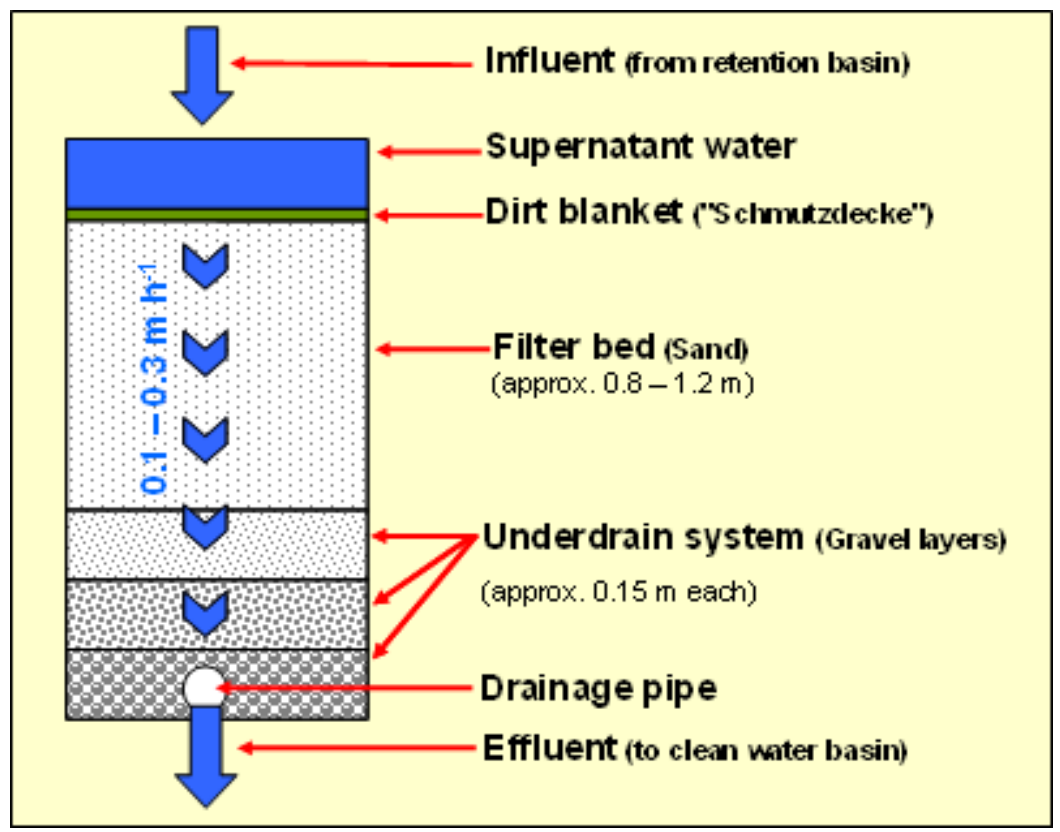

A
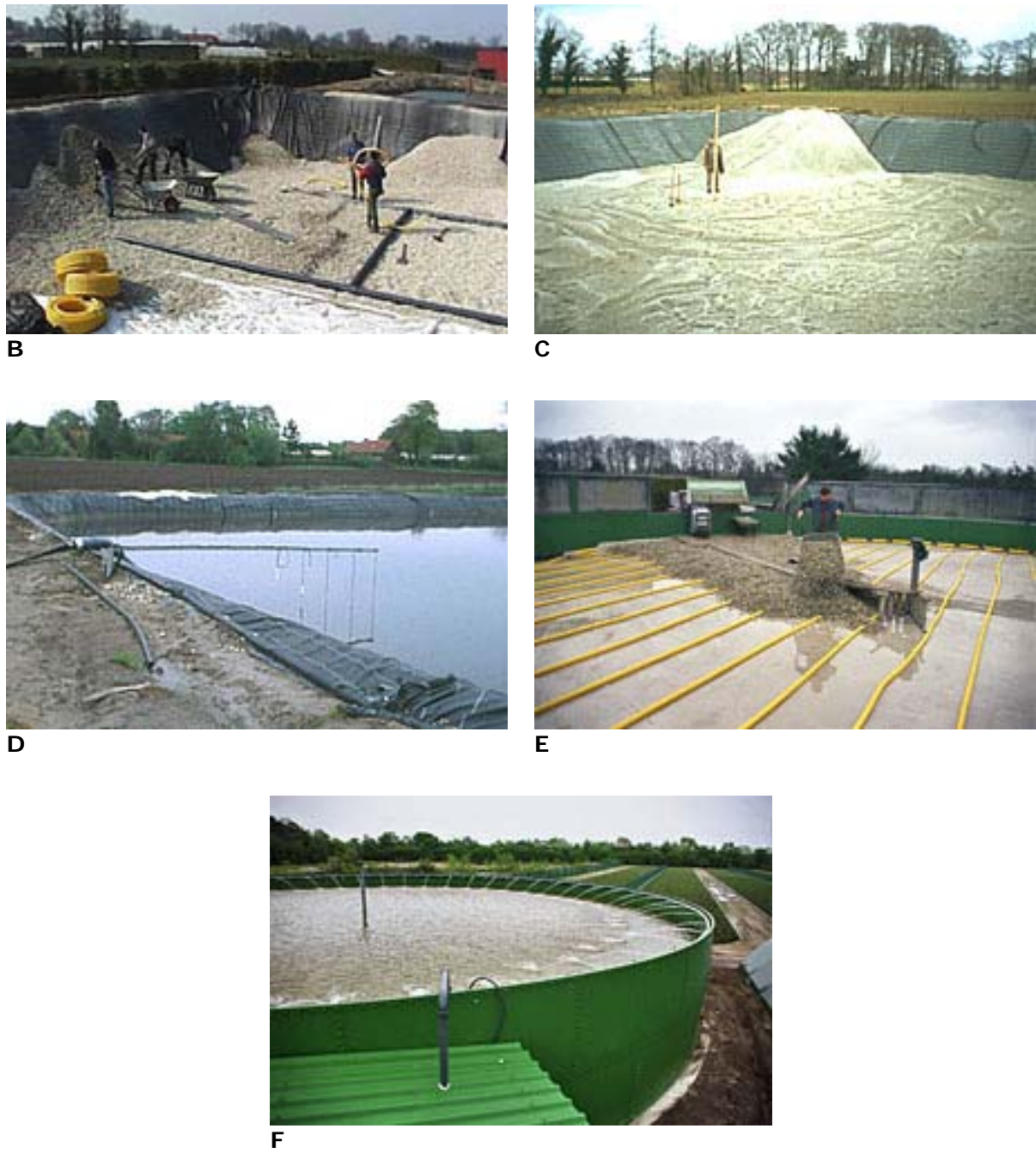

Fig. 2. Slow sand filtration (SSF) systems: (A) schematic diagram of a generic SSF system; (B) construction of the lower drainage system in an earthen basin; (C) completion of gravel layers prior to filling in an earthen basin with sand; (D) earthen basin filter during operation; (E) construction of the lower drainage system on the concrete slab floor of a steel tank; and (F) steel tank filter during operation. 
Table 2. Specification of the filtration systems: Slow sand filter (SSF).

\begin{tabular}{|c|c|c|c|c|}
\hline & SSF 1 & SSF 2 & SSF 3 \\
\hline \multicolumn{2}{|l|}{ Design } & $\begin{array}{l}\text { - earthen basin+ } \\
\text { geomembrane } \\
\text { liner } \\
\text { - covered } \\
\text { - basin depth: } \\
3.3 \mathrm{~m}\end{array}$ & $\begin{array}{l}\text { - steel tank+ } \\
\text { geomembrane } \\
\text { liner } \\
\text { - uncovered } \\
\text { - basin depth: } \\
3.1 \mathrm{~m}\end{array}$ & $\begin{array}{l}\text { - earthen basin+ } \\
\text { geomembrane } \\
\text { liner } \\
\text { - uncovered } \\
\text { - basin depth: } \\
3.3 \mathrm{~m}\end{array}$ \\
\hline \multicolumn{2}{|c|}{ Filter bed area $\left(\mathrm{m}^{2}\right)$} & 324 & 260 & 100 \\
\hline \multicolumn{2}{|c|}{ Design flow rate $\left(\mathrm{m}^{3} / \mathrm{h}\right)$} & 90 & 70 & 30 \\
\hline \multicolumn{2}{|c|}{ I nitial media depth (m) } & $\approx 1$ & $\approx 1$ & $\approx 1$ \\
\hline \multicolumn{2}{|c|}{ Supernatant water (m) } & $\approx 0.5$ & $\approx 0.5$ & $\approx 0.5$ \\
\hline \multirow[t]{4}{*}{$\begin{array}{l}\text { Filter } \\
\text { sand }\end{array}$} & $\begin{array}{l}\text { Effective size } d_{10} \\
(\mathrm{~mm})\end{array}$ & 0.14 & 0.14 & 0.15 \\
\hline & $\begin{array}{l}\text { Uniformity } \\
\text { coefficient }\end{array}$ & 3.07 & 3.07 & 2.67 \\
\hline & $\begin{array}{l}\text { Silt content }(\%) \\
(<0.063 \mathrm{~mm})\end{array}$ & 0.67 & 0.67 & 0.00 \\
\hline & $\begin{array}{l}\text { Acid solubility } \\
(\%) \\
\text { (after } 30 \mathrm{~min})\end{array}$ & 0.30 & 0.30 & 0.08 \\
\hline \multirow{3}{*}{$\begin{array}{l}\text { Under- } \\
\text { drain } \\
\text { system }\end{array}$} & $\begin{array}{l}\text { Depth of support } \\
\text { gravel }(\mathrm{m})\end{array}$ & \multicolumn{3}{|c|}{0.6 (3 layers, $0.2 \mathrm{~m}$ each) } \\
\hline & Gravel size $(\mathrm{mm})$ & \multicolumn{3}{|c|}{2 to 8,8 to 16,16 to 32} \\
\hline & $\begin{array}{l}\text { Diameter of the } \\
\text { drainage pipe } \\
(\mathrm{mm})\end{array}$ & \multicolumn{3}{|c|}{50} \\
\hline \multirow[t]{2}{*}{ Pump } & $\begin{array}{l}\text { Maximum } \\
\text { capacity }\left(m^{3} / h\right)\end{array}$ & 115 & nd & nd \\
\hline & $\begin{array}{l}\text { Maximum power } \\
\text { consumption } \\
(\mathrm{kW})\end{array}$ & 4.4 & nd & nd \\
\hline
\end{tabular}

* Covered temporarily in 2004.

nd $=$ no data calculated.

The LGF filtration system (Fig. 3) was constructed by Shieer Holland Int'l. (Shieer Holland Int'l., Maasdijk, Netherlands) Lava grains (pumice granules) were the filter medium (patented system; Shieer Bio-Filter). With a flow rate of about $0.6 \mathrm{~m} / \mathrm{h}$, water flowed two times faster in this filter system than in SSF. The steel tank contained lava grains in a layer of about $2.2 \mathrm{~m}$ depth, which was infiltrated downward at $17 \mathrm{~m}^{3} / \mathrm{h}$ (Table 3 ). The addition of the activator BioWater Clean (provided by Shieer) was intended to speed up the establishment of beneficial microorganisms in and around the lava grains. To enlarge the contact between the contaminated water and the beneficial microorganisms and prevent clogging in the LGF, an air injection through a complex system of pipes provided continuous circulation around the grains. The nursery ran two filter units. 


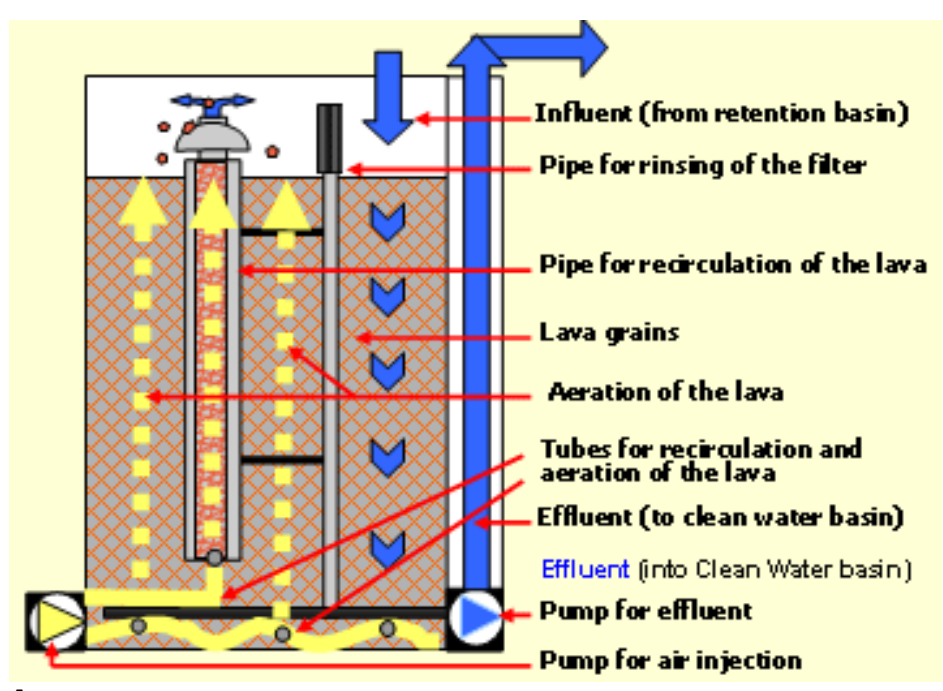

A
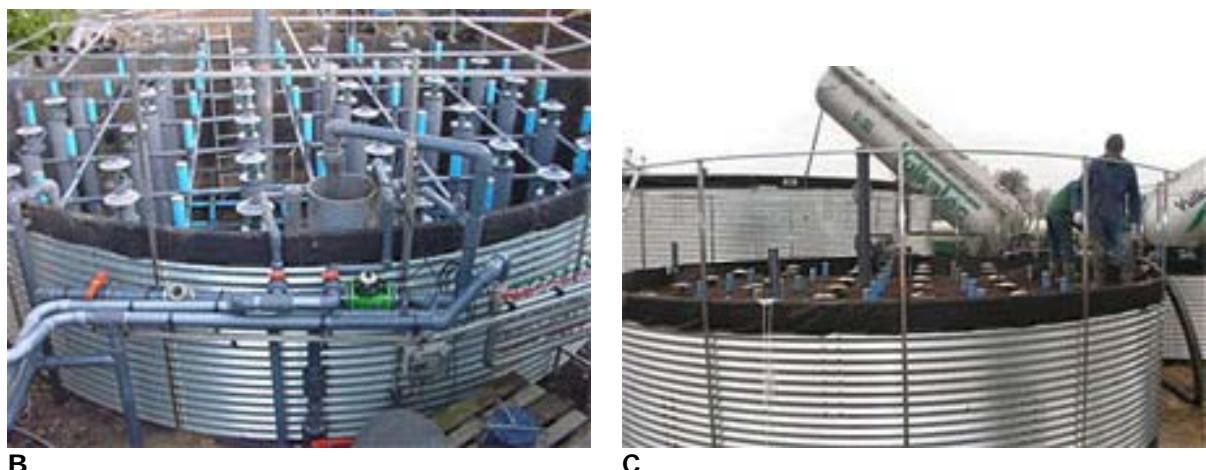

C
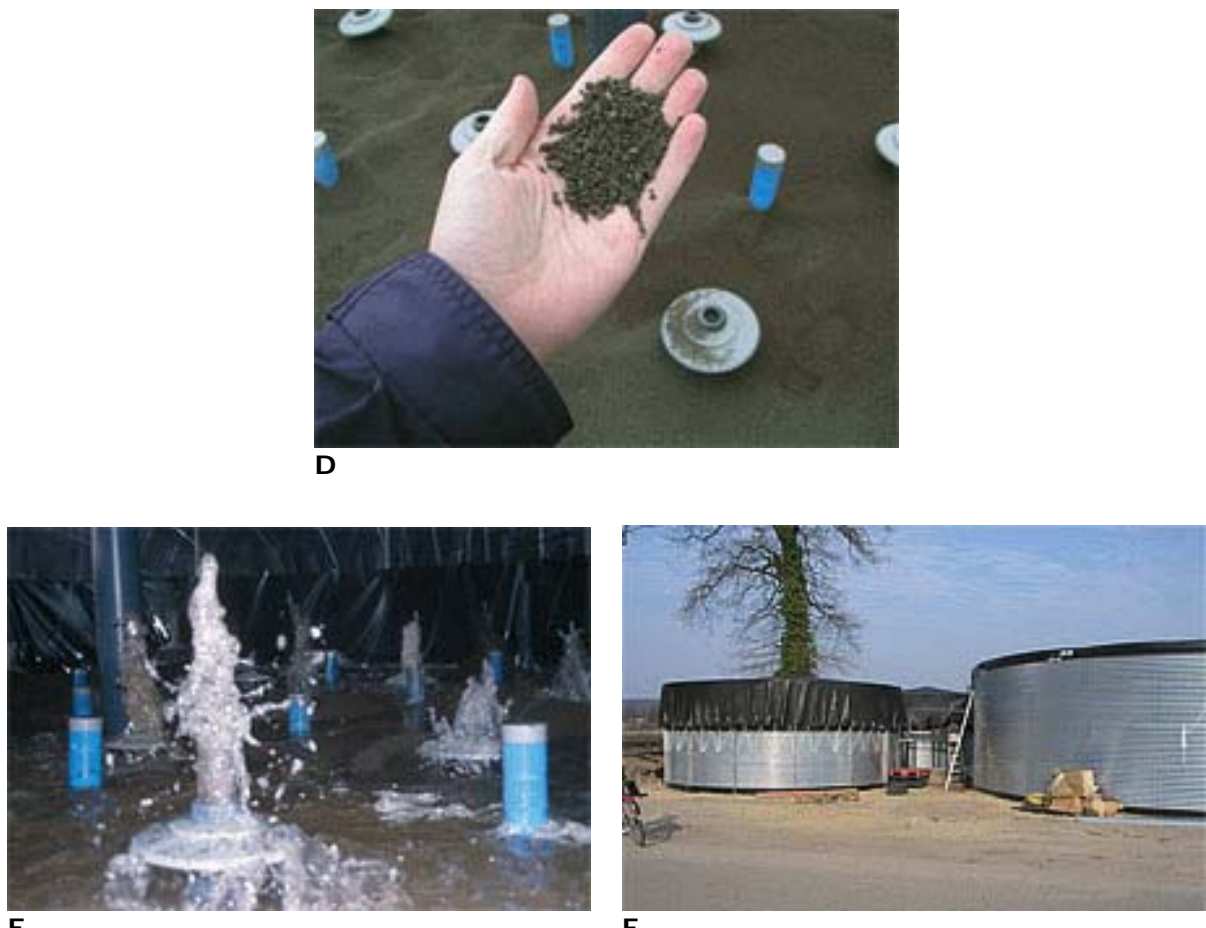

Fig. 3. Lava grain filtration (LGF) system: (A) schematic diagram of a generic LGF system; (B) filter before filled with lava grains; (C) filter filled with lava grains; (D) lava grains; (E) filter operating; and (F) covered filter on left. 
Table 3. Lava grain filter (data shown only for a single unit of two).

\begin{tabular}{|c|c|c|}
\hline \multicolumn{2}{|l|}{ Design } & $\begin{array}{l}\text { - steel tank }+ \\
\text { geomembrane liner } \\
\text { - covered } \\
\text { - basin depth: } 2.5 \mathrm{~m}\end{array}$ \\
\hline \multicolumn{2}{|c|}{ Filter bed area $\left(\mathrm{m}^{2}\right)$} & 30 \\
\hline \multicolumn{2}{|c|}{ Initial media depth $(\mathrm{m})$} & $\approx 2.2$ \\
\hline \multicolumn{2}{|c|}{ Design flow rate $\left(\mathrm{m}^{3} / \mathrm{h}\right)$} & 17 \\
\hline \multirow[t]{2}{*}{ Lava } & Grain size $(\mathrm{mm})$ & 2 to 4 \\
\hline & Media volume $\left(\mathrm{m}^{3}\right)$ & $\approx 66$ \\
\hline Ventilator & Max. power consumption (kW) & 3.4 \\
\hline \multicolumn{2}{|l|}{ Additive } & $\begin{array}{l}\text { biological activator } \\
\text { (Bio-Water Clean) }\end{array}$ \\
\hline \multirow[t]{2}{*}{ Pumps } & Maximum capacity $\left(\mathrm{m}^{3} / \mathrm{h}\right)$ & $223^{x}+18^{y}$ \\
\hline & Maximum power consumption (kW) & $0.3^{x}+1.6^{y}$ \\
\hline
\end{tabular}

Precipitation, I rrigation Water Demand, and Actual Flow Rates

The average annual precipitation in 2003-2006 ranged from $781 \mathrm{~mm}$ (SSF nurseries) to $712 \mathrm{~mm}$ (LGF nursery) with an average monthly precipitation between 36.8 and $92.9 \mathrm{~mm}$ (data from official meteorological stations located closest to the nurseries.)

Water flow was measured continuously with water meters over the four years of the study. The average annual volume of filtered water ranged between 30,000 and 118,000 $\mathrm{m}^{3} /$ year (Fig. 4). Highest water consumption was in summer: between June and August (Fig. 4). The nurseries with SSF filtered an average volume of 15,000 to $20,000 \mathrm{~m}^{3}$ of water per month. A maximum of nearly 40,000 $\mathrm{m}^{3} /$ month was reached in July 2006 for the SSF 2 . The average water demand for LGF was $10,000 \mathrm{~m}^{3}$ per month with a maximum of $14,000 \mathrm{~m}^{3}$ in June 2006. With all SSF systems the filtration capacities were sufficient for commercial production. Only the nursery with LGF needed additional water for a period of 10 days during the very warm and dry summers of 2003 and 2006. This was necessary because the nursery expanded the container area just after the filtration system was installed. The additional water was taken from a well. 

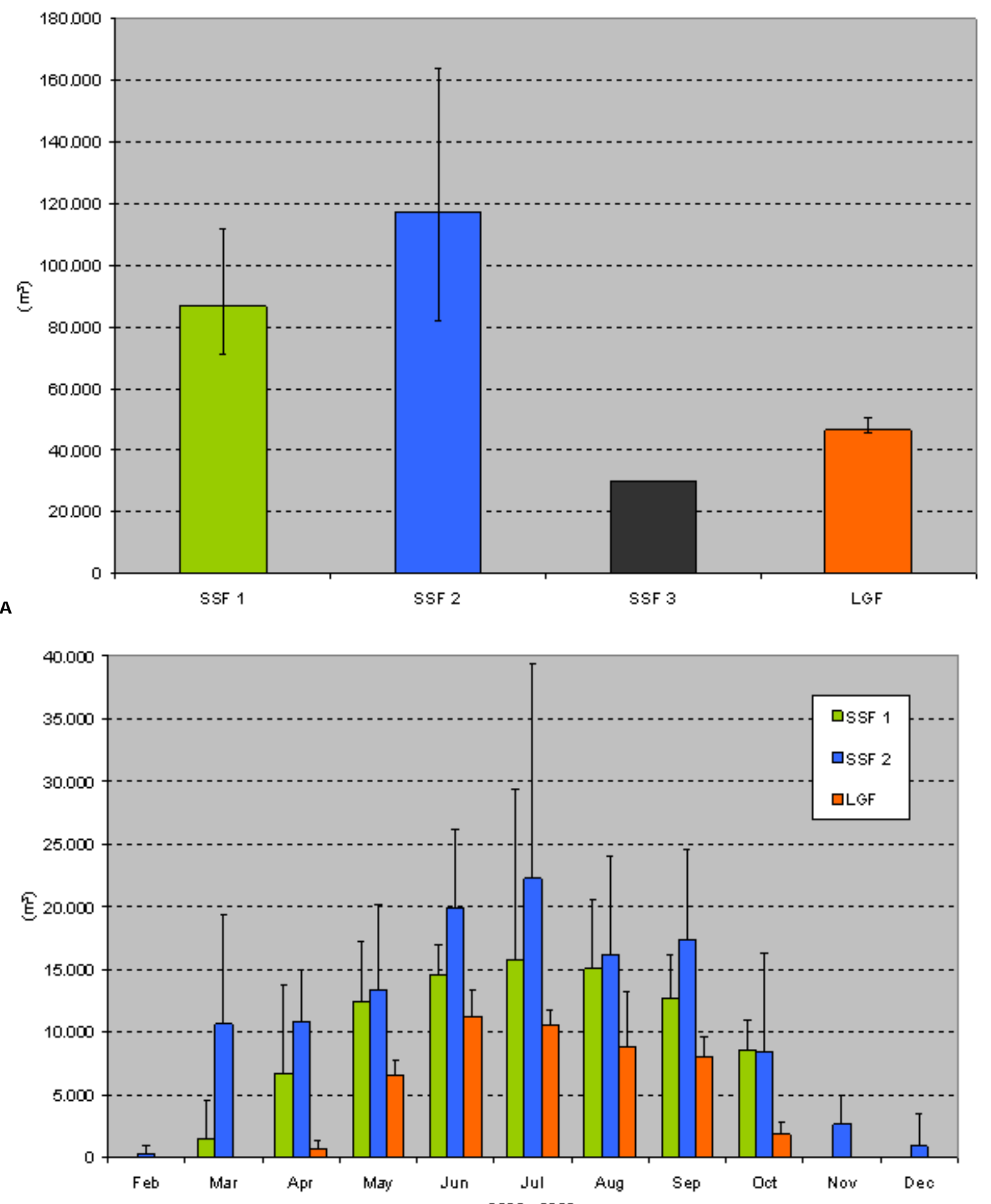

B

$2003 \cdot 2006$

Fig. 4. Average volumes filtered during $2003-2006$ by the four nurseries in the study (SSF = slow sand filtration, LGF $=$ lava grain filtration).

(A) Average annual volumes of filtered water produced by the four nurseries 2003-2006. (Data for SSF 3 estimated from irrigation intensity due to a technical defect in a measuring unit. Error bars show maximum and minimum volumes.)

(B) Average monthly volumes of filtered water produced by SSF 1, SSF 2 and LGF 2003-2006. (Data for LGF not available for 2004 due to technical defect in the measuring unit. Error bars show maximum volumes.)

\section{Costs for Construction and Operating}

The cost calculations were based data provided by nursery extension managers and the nursery managers. For the calculation of labor costs the German official wages (www.tarifregister.nrw.de) from 2003 were used. Costs depended to a high degree on the availability of local material and "know how" in each nursery. To calculate the costs of SSF only data from SSF 1 were used. 
The costs for the construction and installation of the clean water reservoirs ranged from 65,200 € (SSF 1) to 75,000 € (LGF) (Table 4). The annualized total costs (construction costs and running expenses) were 11,200 $€ /$ year for SSF 1 and $17,600 €$ /year for LGF. Part of the variable cost was much higher for LGF (43\%) than for the SSF (21\%). The reasons were the power consumption of the pumps in the LGF and the labor costs for the frequent control monitoring of the lava recirculation systems by the professional horticulturist ('Meister').

Table 4. Comparison of costs for construction and operation ${ }^{\mathrm{s}}$ of a sand filtration system with a lava grain filtration system.

\begin{tabular}{|c|c|c|c|c|}
\hline \multicolumn{2}{|l|}{ Factor } & units & SSF $^{\mathrm{t}} \mathbf{1}$ & $\mathbf{L G F}^{\mathrm{t}}$ \\
\hline \multicolumn{2}{|l|}{ Construction costs } & $(€)^{\mathrm{u}}$ & 65,200 & 75,000 \\
\hline \multirow[t]{2}{*}{$\begin{array}{l}\text { Construction }+ \\
\text { operating costs }\end{array}$} & per year & $(€)^{\mathrm{u}}$ & $\begin{array}{c}11,200 \\
(100 \%)^{\mathrm{w}}\end{array}$ & $\begin{array}{c}17,600 \\
(100 \%)^{x}\end{array}$ \\
\hline & per day & $(€)$ & 31 & 48 \\
\hline \multirow[t]{2}{*}{$\begin{array}{l}\text { Proportion of } \\
\text { the fixed costs }\end{array}$} & per year & $(€)^{\mathrm{u}}$ & $\begin{array}{l}8,800 \\
(79 \%)\end{array}$ & $\begin{array}{l}10,100 \\
(57 \%)\end{array}$ \\
\hline & per day & $(€)$ & 24 & 28 \\
\hline \multirow[t]{2}{*}{$\begin{array}{l}\text { Proportion of } \\
\text { the variable costs }\end{array}$} & per year & $(€)^{\mathrm{u}}$ & $\begin{array}{l}2,400 \\
(21 \%)\end{array}$ & $\begin{array}{l}7,500 \\
(43 \%)\end{array}$ \\
\hline & per day & $(€)$ & 6 & 20 \\
\hline \multirow{2}{*}{$\begin{array}{l}\text { Construction }+ \\
\text { operating costs for } 1 \mathrm{~m}^{3} \\
\text { filtrated water based on: }\end{array}$} & design flow rate ${ }^{y}$ & $\left(€ \mathrm{~m}^{3}\right)$ & 124 & 518 \\
\hline & $\begin{array}{l}\text { annual filtrated } \\
\text { volume }^{z}\end{array}$ & $\left(€ \mathrm{~m}^{3}\right)$ & 0.13 & 0.38 \\
\hline
\end{tabular}

S Calculation period: 2003-2006, no cost calculation for SSF 2 and SSF 3.

$\mathrm{t}$ SSF = slow sand filter, LFG = lava grain filter.

u Rounded to nearest hundred.

$\checkmark$ Calculated depreciation: 10 years, basic interest rate: $5 \%$, general maintenance: $1 \%(13)$, costs for a personal hour: $23.20 € / \mathrm{h}$ for a master gardener and $15.50 € / \mathrm{h}$ for a nurseryman (official German tariffs in 2003 with a $50 \%$ addition for incidental expenses according to www.tarifregister.nrw.de), electricity tariff: $0.23 € / \mathrm{kWh}$ (data from nursery manager 2006), average annual power consumption: SSF $=5,736 \mathrm{kWh}$, LGF $=14,130 \mathrm{kWh}$.

${ }^{\mathrm{w}}$ Cleaning SSF: $2003 / 2004=133 \mathrm{~h}$ by nurseryman (manual), 2005/2006 = $20.5 \mathrm{~h}$ by master gardener (mechanical) resanding SSF $1=4 \mathrm{~h}$ by master gardener every 4 years ( 75 tons sand / 15 $€ /$ ton).

$x$ Operation control + addition of Bio-Water Clean or nitric acid + periodic rinsing of the LGF: $108 \mathrm{~h} /$ year by the master gardener average annual expenses for Bio-Water Clean: 1,692 $€$ /year.

y Design flow rate: SSF 1: 90, LGF: $2 \times 17\left(\mathrm{~m}^{3} / \mathrm{h}\right)$.

${ }^{z}$ Annual filtrated volume: SSF 1: 86,800, LGF: 46,600 (m³/year).

Total costs based on the design flow rate of each filtration system, were $124 €$ per $\mathrm{m}^{3} / \mathrm{h}$ for SSF 1 as compared to $518 €$ per $\mathrm{m}^{3} / \mathrm{h}$ for the LGF (Table 3). Based on the cost of producing $1 \mathrm{~m}^{3}$ filtered water, SSF $1(0.13 €)$ was cheaper to use than LGF (o.38 €) (Table 3).

In all three nurseries with SSF the filter surfaces clogged from time to time and had to be raked 7.5 times and scraped 2.5 times per year on average (Fig. $5 \mathrm{~A})$. This can be reduced in following years as nurserymen gain experience with the filtration systems. In 2004 and 2005 the nursery operating SSF 1 successfully established mechanized, time saving, raking and scraping techniques (Fig. 5B). After three years of operation, SSF 1 and SSF 2 were filled with new sand. SSF 1 was accessible for truckloads of sand to be delivered. After the sand was filled in, the leveling of the filter area was done with a tractor (Fig. 5C). Re-sanding the steel tank construction at SSF 2 was only possible with a skid loader (Fig. 5D) and required many working hours. 

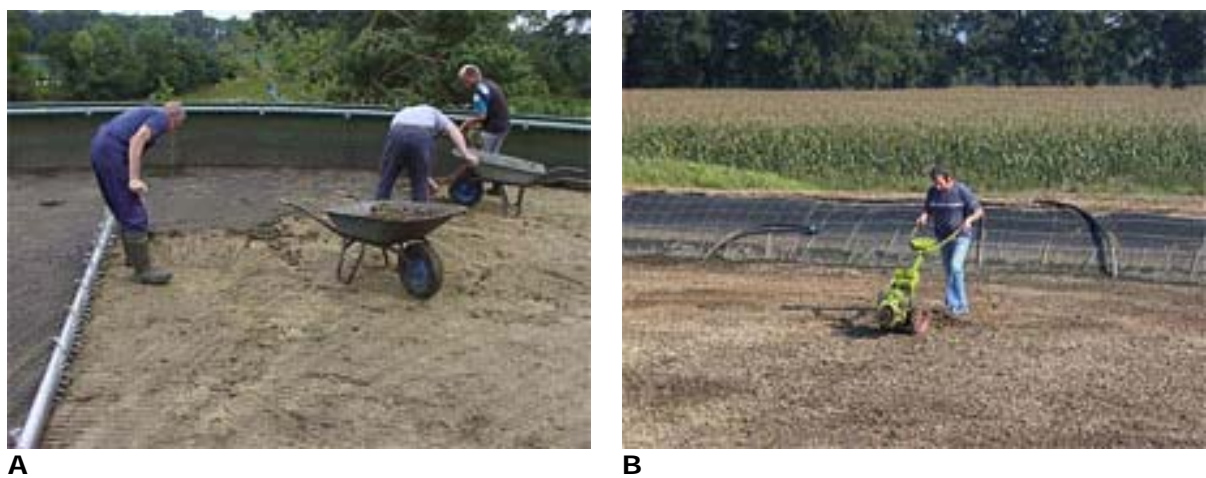

B
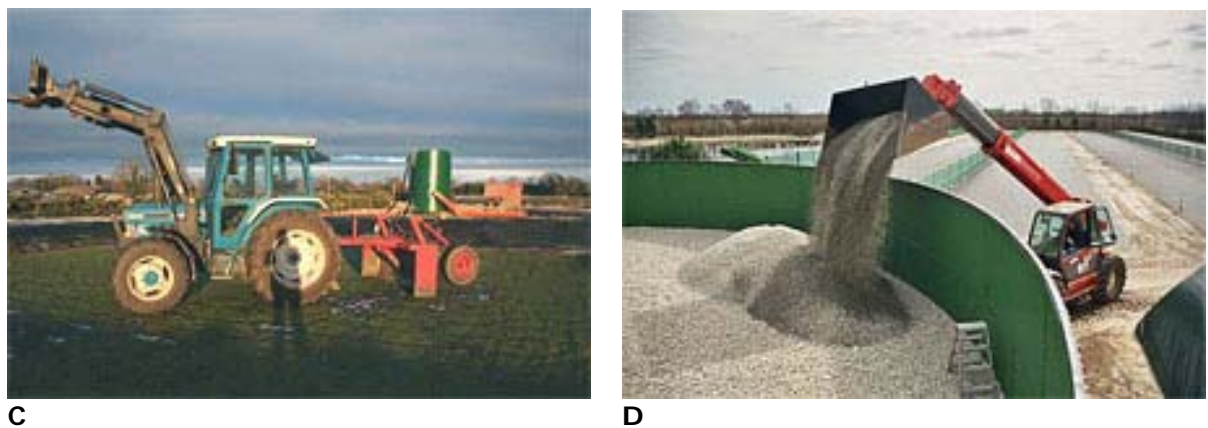

D

Fig. 5. Mechanical scraping and raking of the clogged layer and the re-filling of the slow sand filters: (A) manual scraping and use of a "spiny roller" (left only) to loosen layer; (B) raking with a grubber; $(\mathbf{C})$ tractor with blade used to level sand surfaces; and (D) using a skid loader to fill a steel tank with filter sand.

\section{Water Quality before and after Filtration}

Water samples were taken from the retention reservoirs and from the filtrate three times per year and analysed in an official laboratory of the Chamber of Agriculture Niedersachsen. Statistical analysis was done with SigmaPlot 9.0 with SigmaStat 3.1 (Systat Software Inc., San Jose, CA) using the paired t-test to compare the mean values of the chemical water data before and after filtration to determine significant differences $(\mathrm{P}<0.05)$.

Although there were differences between water from corresponding retention basins and filtrates, the water quality was always of sufficient quality for the irrigation of woody ornamentals in containers according to the recommendations of the local extension managers (data not shown). The naturally high iron amount in the water samples from the retention reservoirs of the three SSF nurseries (up to $2.5 \mathrm{ppm}$ ) were not acceptable. SSF systems reduced the amount of iron significantly to below $0.7 \mathrm{ppm}$. However, it is not recommended that SSF be used to remove the iron because it will clog the filters very quickly. Water with high iron levels must be aerated to eliminate it before filtration. The natural iron level in the water samples from LGF was not unusually high and there was no significant influence on iron by LGF. The $\mathrm{pH}$ values in the retention reservoirs of the four nurseries ranged between 6.6 and 9.8 and in the filtrate samples between 6.9 and 8.2.

\section{Sampling Sites, Dates, and Procedures to Detect Phytophthora} spp.

Based on the results of epidemiological studies with Phytophthora spp. in commercial nurseries (17), water samples (3 liters) were taken at three times during the season (one date each in May, August, October) starting in August 2003 and ending in October 2006, and at four stages in each recycling irrigation system (runoff, retention reservoir, filter effluent, clean water reservoir) (Fig. 1). During 2006 in the SSF 3 nursery only samples from the clean water reservoir were taken due to the modification of the filter.

To detect Phytophthora propagules in the samples a rhododendron leaf test $(16,17)$ was used with modified incubation day/night temperatures: in 2003, 
$15 / 10^{\circ} \mathrm{C}$ and $22 / 18^{\circ} \mathrm{C}$; and 2004 to $2006,20 / 15^{\circ} \mathrm{C}$. In all tests day length was $14 \mathrm{~h}$. Five rhododendron leaves were used to bait each water sample. Three tissue pieces were cut from each leaf ( 15 total/sample) and inserted into carrot piece agar (16) for direct isolation of Phytophthora spp. To determine a semiquantitative detection rate, the percentage of infected bait pieces was calculated per sample. Due to the high number of isolates obtained within the four years of the project, the identity of the Phytophthora isolates was determined only to the genus level using morphological characteristics.

Occurrence of Phytophthora spp. before Filtration (Runoff and Retention Reservoir)

Phytophthora could be detected in the runoff and in the retention basins of all four nurseries, but not at every sampling date (Fig. 6). In the SSF 1 and SSF 3 nurseries all or nearly all samples were contaminated with Phytophthora spp. Furthermore, the SSF 1 samples showed the highest detection rate, especially in 2005 and 2006. In the SSF 3 samples the detection rate varied with the year and the season. The SSF 2 and LGF nurseries had much lower numbers of positive samples. In these nurseries the detection rate per sample was highest in runoff samples. Only 45\% of the SSF 2 samples taken before filtration tested positive. In the nursery with the LGF, only one sample from runoff was contaminated with Phytophthora and $55 \%$ of those from the retention basins. The detection rates per sample were very low in this nursery.

Occurrence of Phytophthora after Filtration (Filtrate and Clean Water Reservoir)

All three SSF systems and the LFG system eliminated Phytophthora spp. totally (Fig. 6). A single sample of the filtrate at LGF was positive Phytophthora in October 2003 after the filtration system was out of order for some days and had been switched on some minutes before sampling. Due to this result the nurserymen pumped the first filtrate back into the retention reservoir after all following disruptions. 

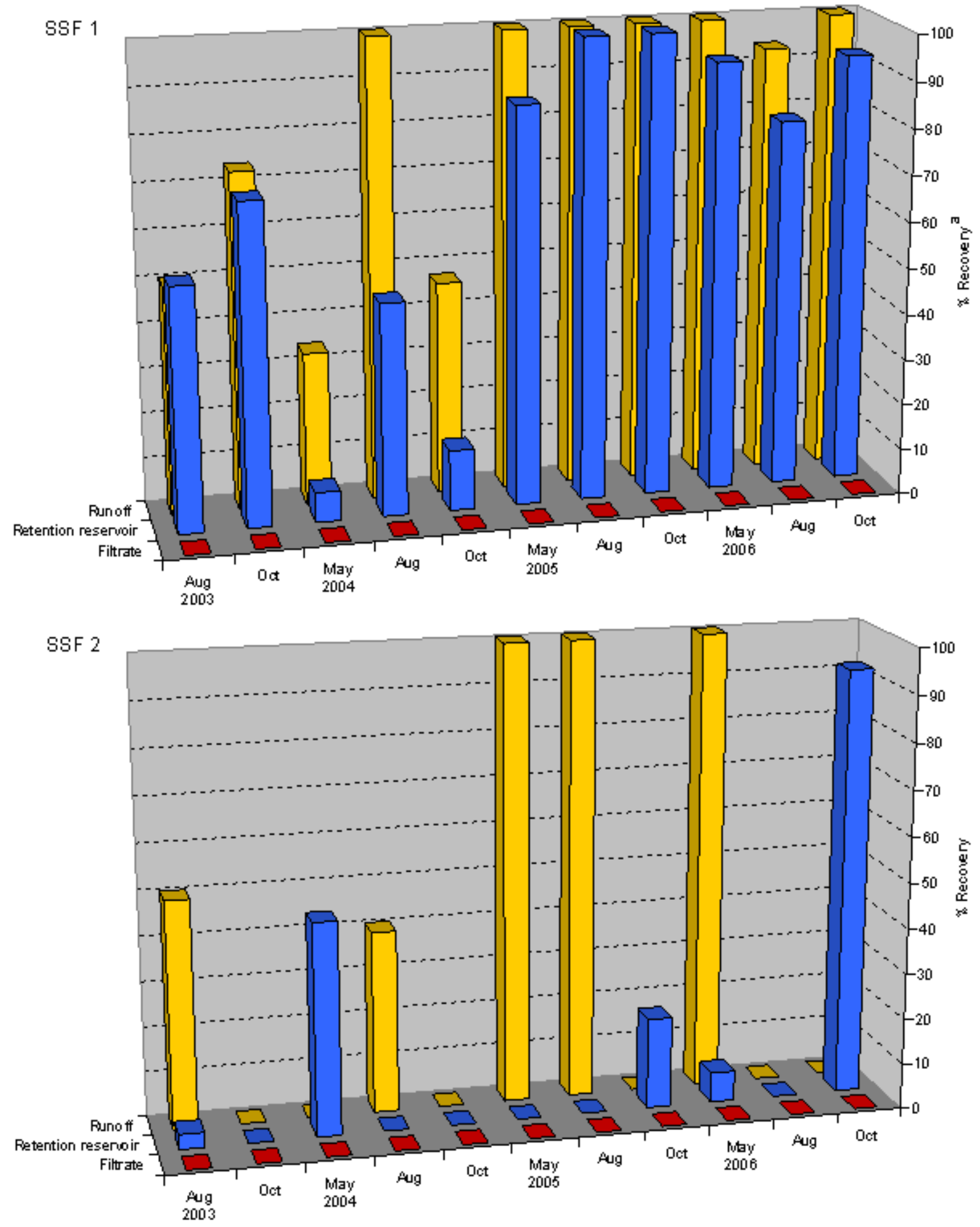

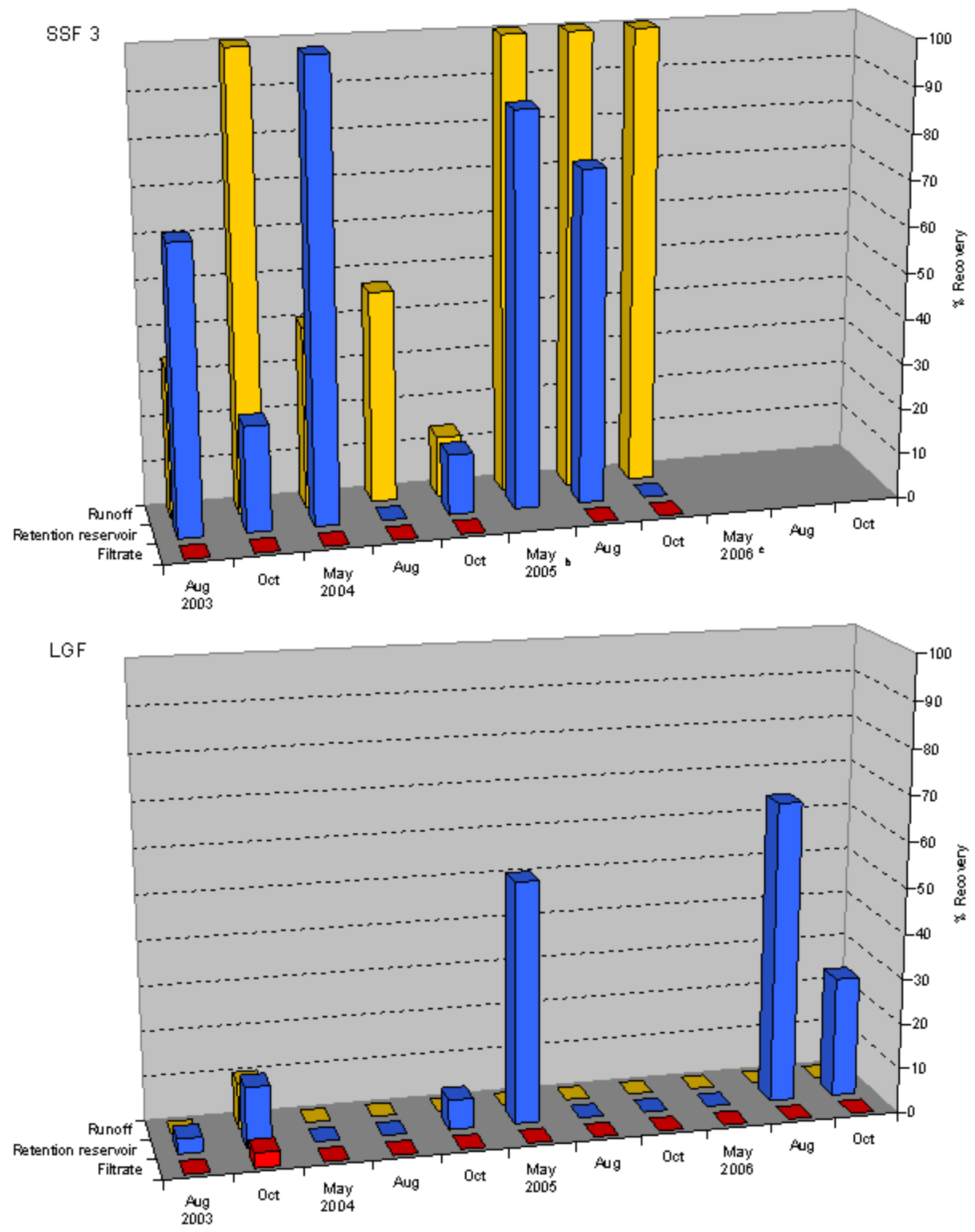

Fig. 6. Percent recovery of Phytophthora spp. from water samples taken before and after filtration with SSF or with LGF. SSF = slow sand filtration, LGF = lava grain filtration .

a Percent recovery based on the number of positive tissue pieces out of 15 tested for each water sample.

b Filter was switched off for cleaning at sampling date.

c No sampling because filter was under modification. 
In all nurseries the filtered water (clean water) was stored in reservoirs. The reservoirs were of different designs and had capacities between 1,000 to $5,000 \mathrm{~m}^{3}$ (Fig. 7). SSF 2 and LGF samples from the clean water reservoirs were never contaminated (Fig. 7A). In these nurseries the clean water was stored without contact with the underlying soil (geomembrane liner in the basin of SSF 2, steel tank in LGF) and the reservoirs were covered (Fig. 7B, 7C, and 7D). SSF 1 and SSF 3 with open air clean water reservoirs (Fig. 7E) showed different results. Only a single tissue piece from a single sample from the clean water reservoir at nursery SSF 1 showed contamination. In contrast, at nursery SSF 3 all samples from the clean water reservoir except one gave positive results, with very low detection rates in 2003 and 2004 and with high ones in 2005. The nursery manager added non-filtered water to the clean water basin when he feared a water shortage. Furthermore in winter 2004/2005 this nurseryman reconstructed the clean water reservoir and a part of the former (contaminated) retention reservoir was integrated into the new clean water reservoir. 


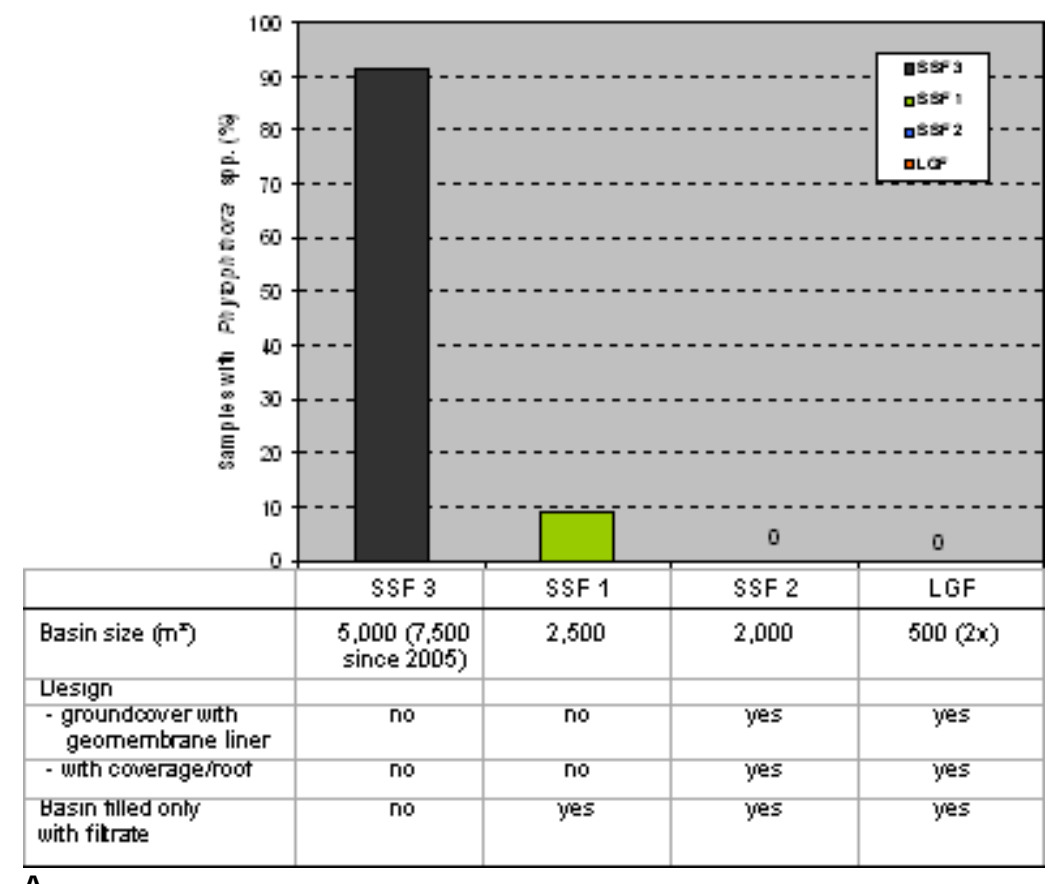

A
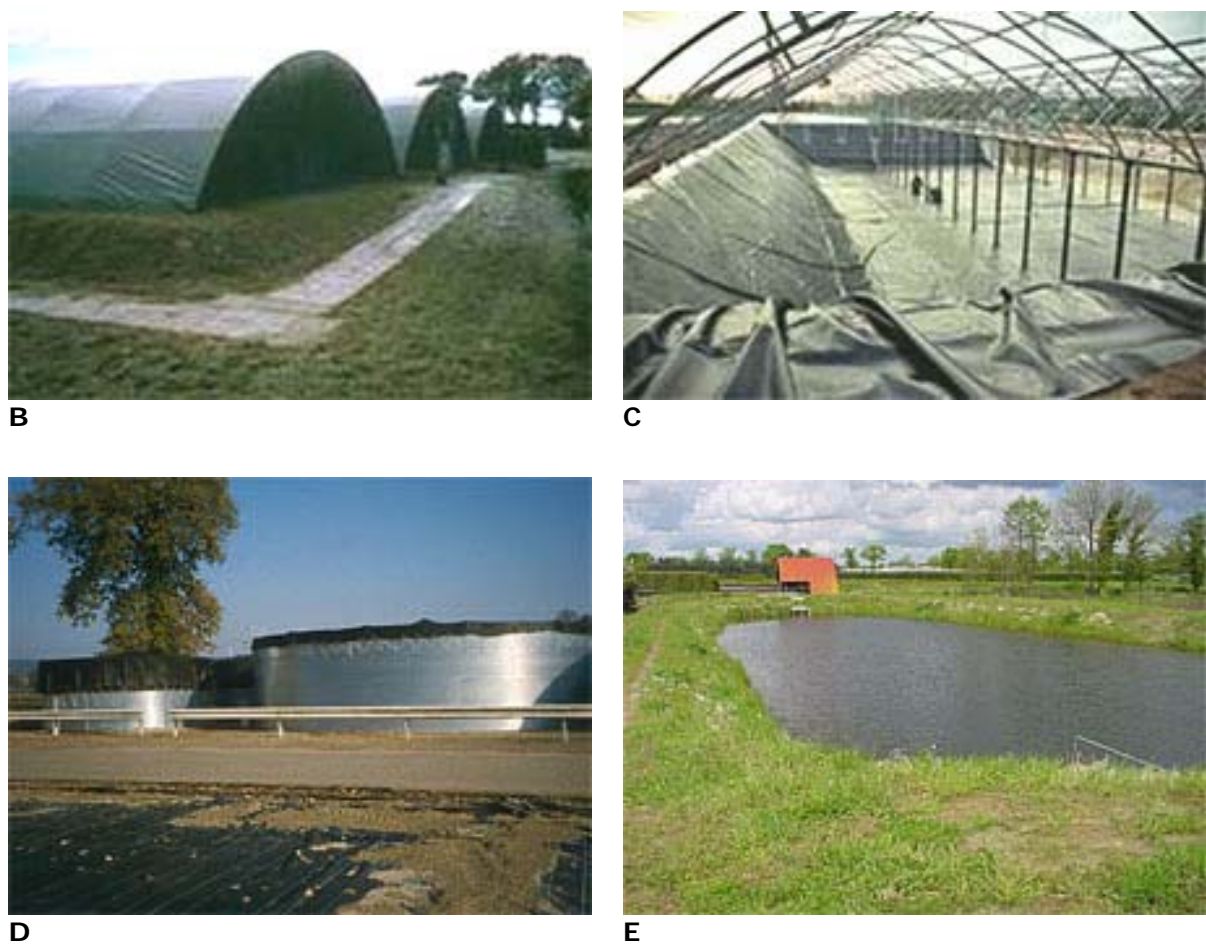

D

Fig. 7. Detection of Phytophthora spp. in clean water reservoirs in relation to protection from recontamination and the quality of water stored: (A) detection of Phytophthora spp. in the clean water reservoirs (SSF = slow sand filter, LFG = lava grain filter); (B) earthen clean water basin lined and covered; (C) construction of an earthen clean water reservoir showing the liner and roof supports; (D) steel tank (right) covered; and (E) earthen clean water basin without a liner and a cover.

\section{Filtration Success in Relation to Air Temperature}

Air temperatures were measured continuously in all four years using the official meteorological station located closest to the nurseries $(15-\mathrm{km}$ maximum distance) to obtain information on the filter activity under climatic conditions of Germany. The three SSF nurseries were located in the same region, so data from the one meteorological station were utilized. 
The climate in Germany is characterized by mild winters and moderate to cool summers. Rain falls year round, with a maximum in the summer. Within the four years of the study the temperatures ranged between -15.3 and $+37 \cdot 5^{\circ} \mathrm{C}$. The average temperatures were between $1.1^{\circ} \mathrm{C}$ in January and $18.6^{\circ} \mathrm{C}$ in July (Fig. 8).

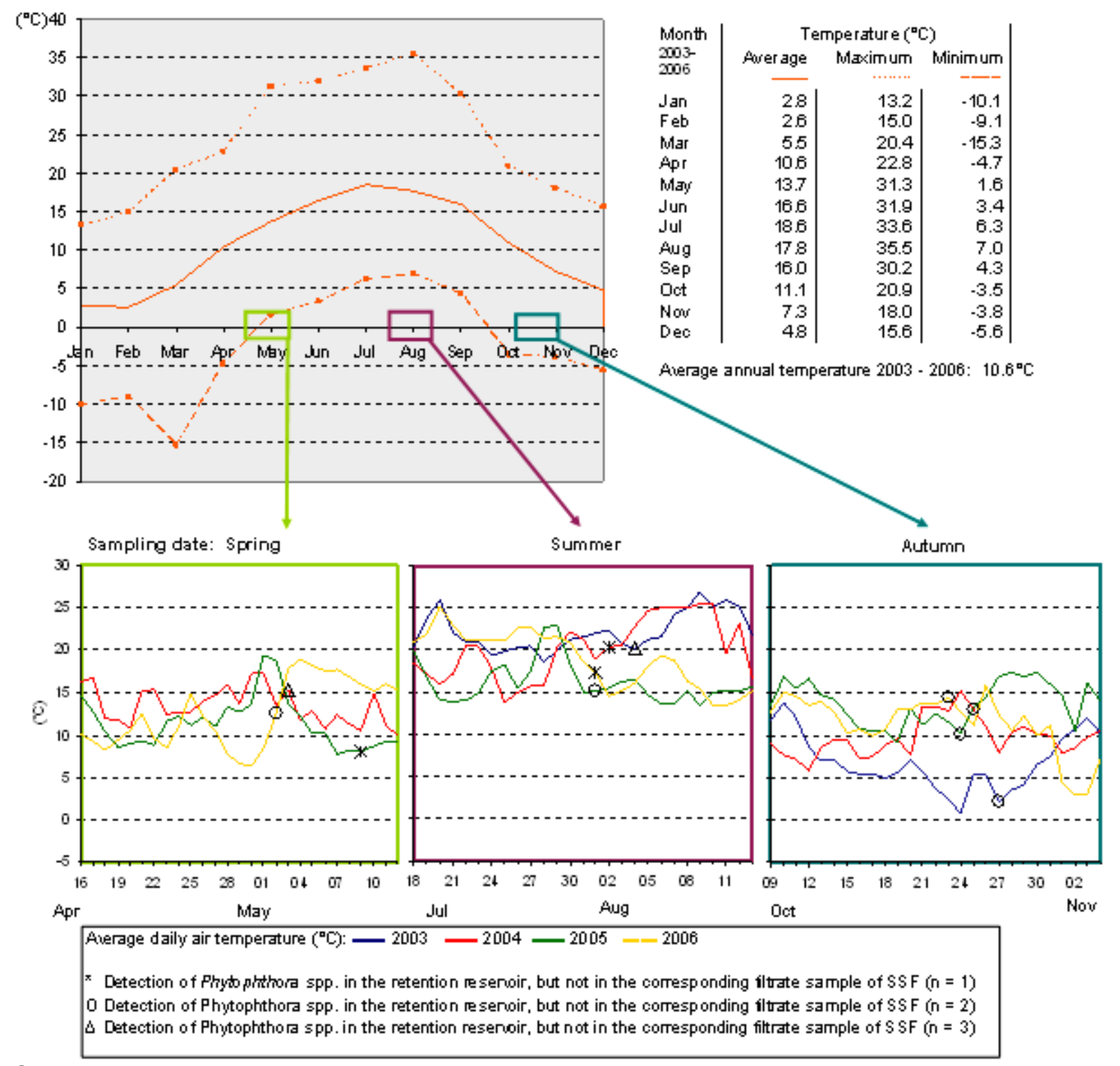

A 


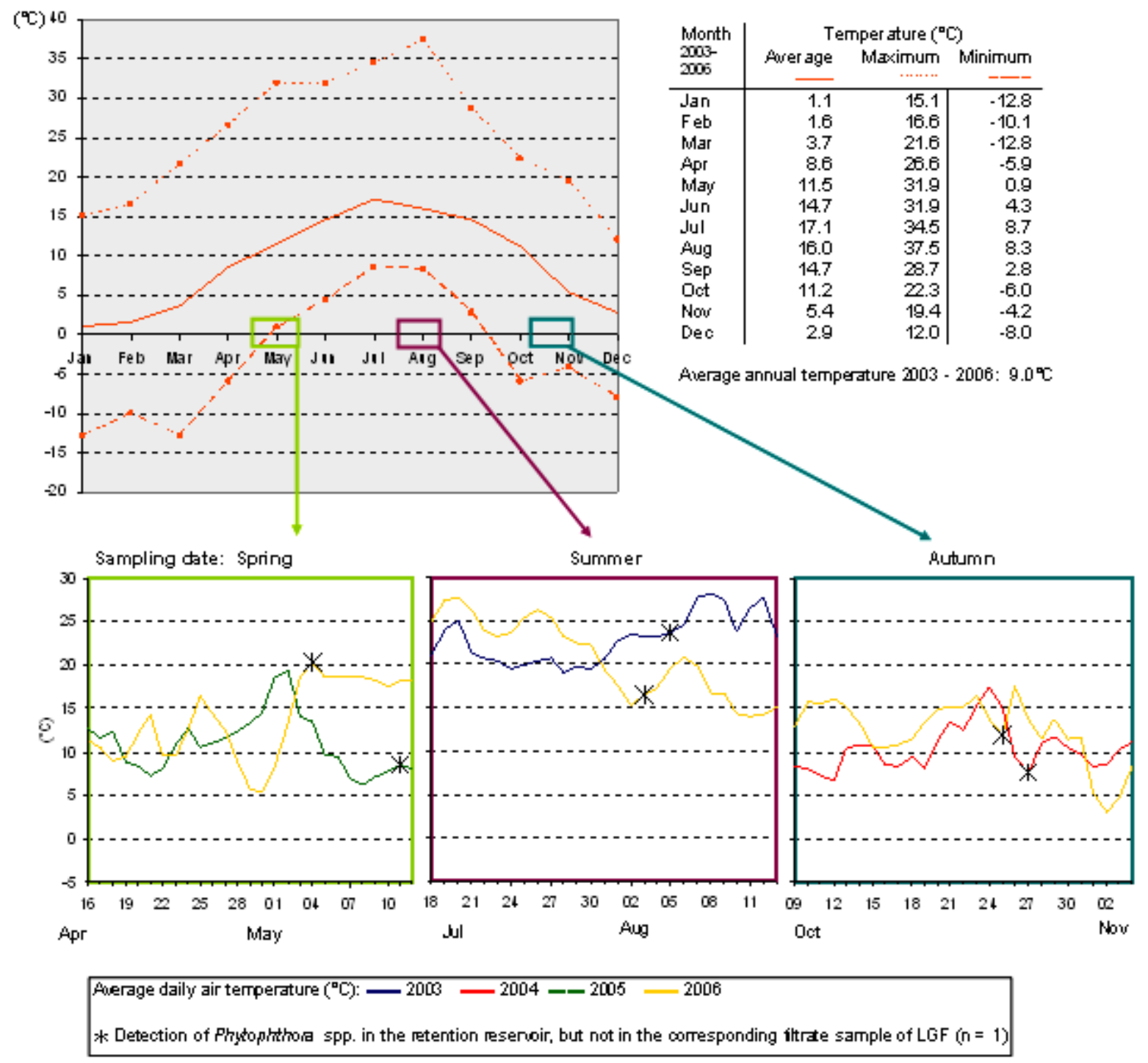

Fig. 8. Effect of average daily air temperature on filtration success from 2003-2006. [Only data from corresponding samples $(*)$ with positive Phytophthora detection in the retention reservoir and no detection in the filtrate are shown (SSF $n=21$, LGF $n=5$ ). SSF = slow sand filter, $L F G=$ lava grain filter.]

(A) Effect of average daily air temperature on filtration success for the SSF systems at SSF 1, SSF 2, and SSF 3.

(B) Effect of average daily air temperature on filtration success for the LGF system.

The nurseries used their filtration systems only during the growing season (usually runs from March/April until October/November). The earliest start of a filter was February 2006 (SSF 2); end of filtering was mid December 2006 (SSF 2). Systems were switched off during winter to avoid potential damage by freezing, and also because of sufficient natural precipitation and low water demands of plants. When filters are switched off, they are drained so that no water remains in the filter. They must be refilled with water when they are switched on again.

Fortnightly temperature profiles before each sampling date were calculated for the corresponding samples with positive Phytophthora detection in the retention reservoir and negative detection in the filtrate (21 of the 29 samples from the SSF, 5 of 11 samples from the LGF). The temperature profiles showed successful filtration between $10^{\circ} \mathrm{C}$ to $15^{\circ} \mathrm{C}$ in spring (April/May), $15^{\circ} \mathrm{C}$ and $23^{\circ} \mathrm{C}$ in summer (July/August), and $5^{\circ} \mathrm{C}$ to $15^{\circ} \mathrm{C}$ in autumn (October) (Fig. 8). Note that the very low autumn temperatures in October 2003 (fortnightly average $4.8^{\circ} \mathrm{C}$ ) did not reduce the filter efficacy of SSF. 


\section{Discussion and I mplications for the Nursery Practice}

SSF and LGF eliminated Phytophthora propagules from the water in open air recycling systems. The climatic conditions between April and October when the filters were operating, did not interfere with the filtration success. Low temperatures around $5^{\circ} \mathrm{C}$ also did not stop the activity of SSF. These results contradict those from the literature that state that a "working temperature" above $15^{\circ} \mathrm{C}(18)$ or 10 to $20^{\circ} \mathrm{C}(14)$ is said to be favorable. Temperatures below 1 to $5^{\circ} \mathrm{C}$ are reported to stop (18) and above $25^{\circ} \mathrm{C}$ to decrease (14) the activity of the SSF. For lava grain filters recommended temperatures for optimum biological activity are $15^{\circ}$ to $25^{\circ} \mathrm{C}$ (11). For the Shieer Bio-Filter (LGF) the minimum temperature should be $8^{\circ} \mathrm{C}$; the optimum temperature is above $13^{\circ} \mathrm{C}$ (Shieer Int., personal communication). TheShieer Bio-Filter action of SSF and LGF is not yet fully understood but it is considered to be a combination of biological and physico-chemical processes. In SSF the active bacterial population was detected in the top layer $(1 \mathrm{~cm})(6)$. In the LGF a similar layer might develop on the lava grain surfaces.

A disinfection technique for water should kill all Phytophthora propagules, regardless of the quantity, and all Phytophthora species present. The calculation of the detection rate with the rhododendron leaf test does not give detailed information on the quantity or the nature of Phytophthora propagules in the different parts of the recycling systems. But a high detection rate with the baits indicates a high number of zoospores in the sample and can be interpreted as a high risk for plant infection compared with samples with a low detection rate. For Phytophthora species no general threshold number of propagules required for infection can be fixed $(4,12)$. We believe that any Phytophthora propagules in the irrigation water are potentially dangerous. Recent studies showed that numbers of propagules can build up through the year $(5,17)$. Furthermore the data indicate that in small retention basins (such as in SSF 1 and SSF 3 ) Phytophthora populations can increase to a higher inoculum level per litre of water more rapidly than in a larger reservoirs (such as SSF 2 and LGF). There was no difference in the filtration success between samples of higher and lower inoculum densities.

Within the scope of this project it was not possible to identify all the trapped Phytophthora isolates. It is known that recycling water can be contaminated with a wide range of species that can vary with season and year $(5,7,8,13,17,19)$. The results clearly show that SSF and LGF eliminated all Phytophthora present in the recirculation systems during the four years of the project. That also suggests that new Phytophthora species introduced into the recycling systems in future can also be eliminated by the filters. Filtration systems can eliminate Phytophthora and also reduce other plant pathogens such as viruses, bacteria and fungi $(2,3)$, thus reducing the threat of water-borne plant pathogens in general.

Good filtration results are useful only if the clean water can be stored and not recontaminated. The example of the SSF 3 nursery clearly shows that clean water reservoirs should never be combined with old reservoirs. Old reservoirs can be contaminated with Phytophthora. Storage in a covered steel tank prevents recontamination. Also earthen basins lined with a geomembrane and a cover over the water surface prevents recontamination. Two or more separate clean water reservoirs would be desirable if one is contaminated and must be cleaned. The experience in nursery SSF 3 also shows that water from retention basins or from rivers should never be used to refill clean water reservoirs, since both of these sources can be contaminated. The risk can be minimized by using well water to refill or top up levels (17). To make sure that there is no Phytophthora in the well water it should be tested during the season. It is also advisable to refill the filter only with clean water from the clean water reservoirs or with well water and always to pump the first filtrate produced after resuming operation back to the retention reservoir. 
This four year study clearly shows that filtration systems can successfully be integrated in commercial production. The SSF and the LGF systems filtered sufficient quantities of water during dry weather periods. The SSF reduced the clogging of the sprinkler nozzles because the fine particles in the water were removed; resulting in reduced maintenance costs. This effect was only observed with filtrate that was stored in well-protected basins.

Reducing costs is one of the major objectives for commercial business. The LGF system was about three times more expensive than the SSF 1 system. But in comparison to other disinfection methods like heat treatment, UV-radiation, ultrafiltration, ozonation, iodine, and hydrogen peroxide plus activator in water recirculation systems, the costs to filter $1 \mathrm{~m}^{3}$ of water with the LFG was similar to these and SSF was one third the cost. Note that for the "non-filtration" methods mentioned, the only cost calculations available are based on horticultural crops in glasshouses and not on large open air recirculation systems in nurseries (10). The main part of the variable costs for SSF was the personnel costs; for LGF it was the energy costs followed by the personnel costs and the costs for the Bio-Water Clean. Since these costs are different in the different countries, the total costs can vary.

Based on all results and experience with the filtration systems, two main considerations should be taken into account before a filtration system is constructed in nurseries:

(i) Larger container nurseries than those involved in the project might demand higher quantities of clean water. Sufficient amount of space for a larger filtration system could be a limiting factor. The LGF system is much more space saving than SSF due to its higher filtration capacity per $\mathrm{m}^{2}$. The LGF system used in this project is the first system constructed outside of a greenhouse and one of the largest filter units constructed by Shieer Holland Int. We conclude that the best filtration would be obtained with independently operated, smaller, SSF units that can be switched on and off as needed based on water demand. This assumes sufficient space to install the SSF system.

(ii) A basic necessity for running SSF is the cleaning of the filter surface. The frequency of cleaning depends on many factors, e.g., raw water quality or flow rate (7). In recent years it is the aim of the nurseries to decrease the frequency of cleaning. The nursery managers are now investigating pre-treatment improvements with a back-flushing filter unit using a special anthracite medium or a constructed wetland facility (Ufer et al., unpublished data). A "spiny roller" for periodic opening of the clogging layer was tested over two years (Fig. 5A). This method is not recommended, because the clogging layer occurred substantially deeper than was affected by the treatment. The pipes of the LGF also clogged. The turn-over of the lava grain from the bottom to the top occurred slowly or stopped totally after some weeks in parts of the filter tank. The manufacturer modified the rinsing system and the filter was filled with new lava grain. Single pipes were back-flushed with higher pressure. However, a complete recirculation of the lava was not reached. In spring 2007 the lava grains were replaced once more completely with grains of well defined size ( 2 to $4 \mathrm{~mm}$ ). Since then the filter has operated without any trouble. If the size of the lava grains is the main cause of the malfunction, the problem can be solved and the calculated running costs (Table 4) should be much lower (about 30\%). Compared to the SSF the LGF is a "high tech" system and for a repair it is necessary to consult the manufacturer. For the SSF, maintenance work (including cleaning of the filter) can mainly be done by the nursery personnel. That should be taken into account when considering the costs.

Both, SSF and LGF are good tools for integrated disease management. The positive acceptance by the nurserymen involved in the project showed that these methods can be used as a preventive plant protection method in commercial production of woody ornamentals and in forest nurseries to produce clean irrigation water. 


\section{Acknowledgments}

We thank Henrike Gottfried and Julia Hauffe for excellent technical assistance and Katrin Kaminski for temporary help. We are also grateful for the very helpful discussions with Thomas Brand, Heinrich Beltz, Ralf Lüttmann, Chamber of Agriculture Niedersachsen, Oldenburg and Bad Zwischenahn and Silvia Fittje, Beratungsring Azerca Nord e.V., Bad Zwischenahn during all project meetings. We are also grateful to Steven Tjosvold and Sharon L. von Broembsen for critical reading of the manuscript and for helpful discussion. The project was supported by the German Ministry for Food, Agriculture and Consumer Protection (BMELV) and the Federal Agency for Agriculture and Food (BLE).

\section{Literature Cited}

1. Backhaus, G. F., Haerig, R., and Hemjoltmanns, E. 1990. Zum Risiko der Verbreitung von Krankheitserregern am Beispiel eines geschlossenen Kultursystems mit Eriken. Taspo-Praxis 18:62-71.

2. Barth, G. 1998. Investigation of sand filtration for nursery recycling systems. Hort. Res. \& Dev. Corp., Gordon, New South Wales, Australia.

3. Berkelmann, B., Wohanka, W., and Krczal, G. 1993. Transmission of pelargonium flower break virus by recirculating nutrient solutions with and without slow sand filtration. Acta Hort. 361.

4. Bruck, R. I., and Kernly, C. M. 1983. Effects of metalaxyl on Phytophthora cinnamomi root rot on Abies fraseri. Plant Dis. 67:688-690.

5. Bush, E. A., Hong, C. X., and Stromberg, E. L. 2003. Fluctuations of Phytophthora and Pythium spp. in components of a recycling irrigation system. Plant Dis. 87:1500-1506.

6. Calvo-Bado, L. A., Pettitt, T. R., Parsons, N., Petch, G. M., Morgan, J. A. W., and Whipps, J. M. 2003. Spatial and temporal analysis of the microbial community in slow sand filters used for treating horticultural irrigation water. Appl. Env. Microbiol. 69:2116-2125.

7. Cleasby, J. L. 1991. Source water quality and pretreatment options for slow sand filters. Pages 69-10o in: Slow Sand Filtration. G. S. Logsdon, ed. Am. Soc. Civil Engin., New York, NY.

8. Hong, C. X., and Moorman, G. W. 2005. Plant pathogens in irrigation water: Challenges and opportunities. Crit. Rev. Plant Sci. 24:189-208.

9. Huisman, L. and Wood, W. 1974. Slow Sand Filtration. Online. World Health Organisation, Geneva, Switzerland.

10. Krusche, S., Range, H., and Sennekamp, W. 1995. Nährlösungs- und Gießwasserentkeimung für gärtnerische Kulturen unter Glas.

Landwirtschaftskammer Westfalen-Lippe, Gruppe 33 Gartenbau, Lehrschau IPM 1995, Münster, Germany.

11. Le Quillec, S., Déniel, F., Rey, P., and Guillou, A. 2005. L'épuration des eaux de drainage par biofiltration. Centre Technique Interprofessionel des Fruits et Légume (Ctifl).

12. Lutz, A. L., and Menge, J. A. 1991. Population fluctuations and the number of propagules of Phytophthora parasitica that occur in irrigated citrus groves. Plant Dis. 75:173-179.

13. MacDonald, J., Ali-Shtayeh, M. S., Kabashima, J., and Stites, J. 1994. Occurrence of Phytophthora spp. in recirculated nursery irrigation effluents. Plant Dis. 78:607-611.

14. Pyper, G. R., and Logsdon, G. S. 1991. Slow Sand Filter Design. Pages 122-148 in: Slow Sand Filtration. G.S. Logsdon ed. Am. Soc. Civil Engin., New York, NY.

15. Runia, W.T. 1993. A review of possibilities for disinfestations of recirculation water from soilless cultures. New Cultivation systems in Greenhouse. Acta Hort. 361.

16. Themann, K., Werres, S., Lüttmann, R., and Diener, H. A. 2002. Comparison of different methods to detect Phytophthora spp. in recycling water from nurseries. J. Plant Pathol. 84:41-50.

17. Themann, K., Werres, S., Lüttmann, R., and Diener, H. A. 2002. Observations of Phytophthora spp. in water recirculation systems in commercial hardy ornamental nursery stock. Eur. J. Plant Pathol. 108:337-343.

18. Van Kuik, A. J. 1994. Eliminating Phytophthora cinnamomi in a recirculated irrigation system by slow sand filtration. Med. Fac. Landbouww. Univ. Gent. 59:1059-1063. 
19. von Broembsen, S. L., and Wilson, S. K. 1998. Occurence of Phytophthora spp. in nursery runoff and recycled irrigation water. Phytopathology 90:S92

20. Werres, S., Wagner, S., Brand, T., Kaminski, K., and Seipp, D. 2007. Survival of Phytophthora ramorum in Recirculating Irrigation Water and Subsequent Infection of Rhododendron and Viburnum. Plant Dis. 91:1034-1044.

21. Whiteside, J. O., and Oswalt, T. W. 1973. An unusual brown rot outbreak in a Florida citrus grove following sprinkler irrigation with Phytophthora-infested water. Plant Dis. Rep. 57:391-393

22. Wohanka, W. 1993. Slow sand filtration and UV radiation; Low cost techniques for disinfection of recirculating nutrient solutions or surface water. Pages 497-511 in: ISOC Proc. of the 8th Intn'l Congr. on Soilless Culture, Hunter's Rest, South Africa, 2-9 October 1992. Secretariat of ISOSC, Wageningen, Netherlands. 